\title{
The role of the audit committee in improving earnings quality: The case of industrial companies in GCC
}

\author{
Allam Hamdan \\ Accounting and Economics Department, College of Business and \\ Finance, Ablia University, Manama, Babrain \\ abamdan@ablia.edu.bh
}

\begin{abstract}
We examine three audit committee characteristics, including the audit committee independence, the size of audit committee, audit committee diligence/meetings to identify if any of these characteristics differentially impact earnings' quality. The sample included 23 industrial firms from the Gulf Cooperation Council (GCC) financial markets during the period of 2014-2018. To achieve this goal, the study measures earnings quality using DeAngelo (1981) model and accrual accounting. By using the panel fixed-effect regression, our analysis reveals that bigger audit committees with more independence are more likely to be associated with earnings quality in GCC industrial firms. We also find that the audit committee diligence/meetings have no impact on earnings quality.
\end{abstract}

Keywords: earnings quality, audit committee, industrial firms, GCC.

JEL Classification: G3, M42, O16

\section{INTRODUCTION}

Increasing emphasis placed on corporate governance has elevated the role of audit committees. Accordingly, the interest in the role of audit committees has recently increased inasmuch as it serves as the tool of corporate governance given its responsibility for not only auditing firm's financial reporting and disclosure process but also monitoring the choice of accounting policies and principles, evaluating regulatory compliance and corporate ethics, and overseeing the hiring, performance, and independence of the external auditor (Larcker \& Tayan, 2011). Pucheta-Martnez and Fuentes (2007) found that audit committee plays a vital role in the process of monitoring financial statements and minimizing conflict between management and external auditor. As a specialized committee of the board of directors, the audit committee plays a significant role in improving accounting information quality. Specifically, the board of directors has advisory and oversight roles in consulting with management on firm's strategic and operational decisions, evaluating management's contribution to performance, and allocating executive compensation accordingly (Cho \& Song, 2017). 
In 1999, the Blue Ribbon Committee (BRC) sought to develop recommendations which would help improve financial reports through consolidating the audit committee's role. It identified a series of factors -- the size of the committee, experience and financial knowledge of its members, degree of independence and frequency of meetings -- common for active audit committees. In July 2002, Sarbanes-Oxley Act became the most significant and comprehensive American legislation since the forming of SEC, with its sweeping impact on companies and independent accountants. Sarbanes-Oxley Act has reformed matters dealing with the right of declaration, submission of financial reports by foreign general company's corporate governance, and monitoring of accounting auditors. Article 301 of the legislation, in particular, articulated the formation and duties of an audit committee addressing the integrity and credibility of the report of the external auditor whose hands might be otherwise tied by an overweening management.

The GCC financial markets Act compels publicly-listed companies to establish an audit committee formed by no fewer than three independent directors, free of any conflict of interest with the company. Additionally, audit committee members should evince a substantial track of record involving recent experience in the financial sector with technical background in accounting and finance, sufficient to evaluate complex corporate financial statements in the backdrop of the international accounting practices and principles. The meeting schedule of the audit committee should be in sync with that of the company board and the committee is required to convene, at minimum, four times per year. In GCC, the rules for publicly-listed companies to establish an audit committee is a recent policy development. Insights into the efficacy of audit committees as management oversight mechanisms can be drawn based on the analysis of the relationship between audit committee characteristics, on the one hand, and earnings quality, on the other. The term "earnings quality" has been identified with "the persistence, the informativeness, sustainability, stability, predictability, and lack of variability of reported earnings" or, in more narrowly focused terms, as "the proportion of income attributable to the core operating activities of a business".

Providing additional evidence about the relationship between audit committee characteristics and earnings quality among corporations in an emerging market constitutes the major contribution of the current study to the already existing literature. This study explores the relationship between audit committee characteristics and earnings quality in the GCC industrial firms. To examine the relationship between audit committee and a firm's earnings quality, audit committee data of the listed industrial firms at the GCC financial market from 2014 to 2018 was collected with the view to assess the extent to which audit committee characteristics impact earnings quality.

The remainder of the paper is organized as follows. The next section reviews the related prior literature and presents our hypotheses. Subsequently, after a discussion of the applied research methods, the results are presented. Conclusions are then drawn followed by limitations of the study.

\section{LITERATURE REVIEW AND HYPOTHESES}

Investors concerned with earnings quality increased during the last decade after many international companies disseminated announced about non-authentic and temporary earnings as part of their quarterly reports. Accordingly, investors have become more cautious in evaluating net earnings in using published information to form a judgment regarding firm value. Investors' interpretations of the valuation implication of an earnings signal may vary in light of differentials in resources, financial knowledge, and analytical skills at the disposal of individual investors. Earnings quality has been an important focus in several studies. However, there is no universal and single definition to measure for earnings quality (Vo and $\mathrm{Chu}, 2019)$. These differences of opinions are more likely with low-quality earnings, which are harder to interpret (Abdel-Meguid et al., 2019). Ohlson and Feltham (1995) define earnings quality as the investor's ability to predict future abnormal earnings depending on recent data. However, Qaraqish (2009) 
views earnings quality as a genuine expression by companies reflective of actual earnings absent deliberate misrepresentation or exaggeration. Many of the definitions of earnings quality revolve around the two previous ones. Good earnings quality means that present earnings provide an accurate picture of the company and its sustainability --- what Du et al. (2019) dubbed "earnings fidelity:" the degree to which earnings augur the veritable financial condition of the firm. In making investment decisions, investors ascribe a high weight to evidence indicative of good earnings quality (Dechow and Schrand, 2004). Investing in low-earnings-quality securities is inadvisable in that the investor bears substantial downside risk not adequately compensated for by expected returns (Schipper and Vincent, 2003) in asmuch as, inter alia, good earnings quality might be used as an indicator of the likelihood of payout of dividends. Farinha and Moreira, (2007) ascertained a relationship between earnings quality and dividends with the expected dividends being paid increasing as the quality itself improves.] Firms with bad earnings quality generate integrity and credability issues ballooning "crash risk" in incidents of financial instability and upheaval (Silva, 2019) Using data drawn from Vietnamese publicly traded companies, Huynh (2019), linking the absence of organizational reputation with bad earnings quality in a "vicious circle," provides empirical support to Silva's crash risk theory.

Bagava (2006) ranks a determination of earnings quality as of high priority in financial statement analysis. Minimally, good earnings quality obtains in the absence of indicators of bad earnings quality: the red flags of restatements of prior reported corporate results and Secutity and Exchange (SEC) comment letters (Du et al., 2019). Another harbinger of bad earnings quality is a diverse range in öpinion among investors of earnings declared in corporate reports (Abdel-Meguid et al., 2019) ambiguity dubbed "differential interpretations." In the PRC, firms evincing a higher level of corporate social responsability tend to demonstrate commensurately higher earnings quality and, at least with respect to non-state-owned firms, mitigate deleterious effects of earnings management (Rezaee et al., 2020). From an alternate perspective, Tee and Rassiah (2020), tapping into data of publicly traded companies in Malaysia, link earnings quality diversity to ethnicity on boards in which the former varies directly with the latter. Apparently, however, political connections in boards undermine the positive return of ethnicity on earnings quality. Other factors may also inhere. In an unusual study, Lobanove and Barua (2019) find that earnings quality improves in firms selling dual-class (as opposed to single-class) stock (although the reverse paradoxically obtains with respect to the "quality of the information environment"). Understanding earnings quality plays an important role in the process of financial analysis; earnings of high-quality help financial analysts in analyzing three basic informational dimensions spanning: present functional performance of the company, future functional performance and value of the company. (Dechow \& Schrand, 2004).

Regarding the relationship between voluntary disclosure and earnings quality, Karajeh, (2020) founds that Malaysian companies with high earnings quality are more likely to disclose information voluntarily to help stakeholders. Furthermore, this study provides original evidence that institutional ownership and managerial ownership play concurrent roles as moderating variables that influence propensity of voluntary disclosures contributing to enhanced earnings quality. In examining how a firm's engagement in socially responsible activities affects the quality of financial reporting in the Korean financial market in terms of earnings management practices, Yoon et al. (2019) suggest that ethical predispositions associated with production of high-quality financial reports stem significantly from firm characteristics. Vo and Chu (2019), utilizing data from publicly traded non-financial corporationation in Vietnam, suggests that foreign institutional shareholders with extensive management skills might have ability to assist firms in which they have invested with improvement in quality of reported earnings.

Controversy attends the concept of earnings quality. Some use earnings continuity as a standard of its quality (Altamuro \& Beatty, 2009) insofar as the continuity of earnings refers to the relationship between 
the present earnings with the future ones. Abdel-Meguid et al. (2019), in investigating the association between earnings quality and investor disagreement regarding the valuation consequences of earnings announcements, show that low earnings quality is associated with variability in interpretations of earnings announcements. As earnings are divided into cash flows and accruals, good quality earnings means that cash flows are more than accruals (Sloan, 1996). Others maintain that earnings quality is better once free from earnings management practices: the less the discretionary the accruals, the better the quality (Francis et al., 2004; Dechow \& Dichev, 2002; Al-Sharif, 2008). Alternative gauges for measuring earnings quality engenders variability in valuations; the same company might be accorded a higher or lower quality level depending on the earnings quality concept adopted. (Abdelghany, 2005).

The audit committee has a major role in management oversight, monitoring and advising when it comes to the implementation of internal accounting control systems and financial statement preparation (Ammer \& Ahmad-Zaluki, 2017). In a sample of Australian companies selected prior to legislation mandating establishment of audit committees on an obligatory basis under Australian corporate law in 2003, Baxter and Cotter (2009) strove to observe the formation and characteristics of audit committees in light of their impact on earnings quality. The results of that study convincingly demonstrated that forming an audit committee reduces earnings management without lowering accrual estimation errors. The study also uncovered a significant direct relationship between the level of the financial experience of members of audit committee and earnings quality improvement. Other audit committee characteristics appeared unrelated to earnings quality. Other studies uncovered sundry alternative factors influencing earnings quality. Teitel and Machuga (2010) found that effective corporate governance contributed to improvement of earnings quality. Wang et al. (2016) also reported that effectiveness in audit committee work ouput correlates positively with both information transparency and earnings quality in Taiwan. Baioco and Almeida (2015) report a similar dynamic in Brazil with respect to the effect of audit committees on relevance of earnings. However, these findings have to be tempered by the more nuanced observations of Chen and $\mathrm{Du}$ (2013) in their analysis of the impact of audit committees in Japan, where some firms only champion audit committees as a "fashion label." Such symbolic adopters evince no increment in goodness of earnings quality upon establishment of internal audit committees. Only substantive adopters, who implement with assiduity and earnestness the monitoring function, generate real improvement in earnings quality in the firm.

In relating external auditor qualified report incidence to audit committee characteristics (independence, size, meeting times, and financial experience), Martinez and Fuentes (2007) considered a subset of Spanish listed companies that voluntarily formed audit committees pursuant to the Spanish Olivencia corporate governance code adopted in 1998. They determined that the probability of the company receiving a qualified report resulting from errors or non-commitment is independent of the presence of audit committee; however, that probability is statistically significantly impacted by the size and independence of members of the audit committee. Using size of audit committee and size of board of directors as control variables, Carcello and Neal (2003) found a significant positive relation between audit committee independence and financial reports quality. Felo, et al. (2003), focusing on the relation between audit committee characteristics "regarding: financial experience, independence, and committee size", and financial information quality, noted an inverse relationship between independence of audit committee members and financial deviations but a direct relationship between financial experience of audit committee members and size of audit committee, on the one hand, and, on the other, quality of published financial information. A number of researchers (Beekes, Pope and Young, 2004; Ahmed and Duellman, 2007; Lara, Osma and Penalva, 2009; Rezaee and Tuo, 2019; Zhang, 2019; Zalata et al., 2019; Du et al., 2019) corroborate that key corporate governance mechanisms within the financial reporting process provide an additional layer of monitoring that enhances earnings quality. 
In line with the above-recited literature review, the following hypotheses are posited along the following rubrics:

Independence of audit committees is associated and earnings quality

H1: Increased independence of audit committees is associated with earnings quality.

The independence of audit committee members impacts efficiency in preparing and overseeing the financial statements. The independence of audit committee members is considered a mean to control the process of financial reporting. Therefore, this characteristic can be used as an indicator to measure the earnings quality (Baxter \& Cotter, 2009).

Size and meetings of audit committees is associated and earnings quality

H2: Increased audit committees' size is associated with earnings quality.

H3: Increased audit committees' meetings are associated with earnings quality.

Increased activity-level and size of audit committees has been linked to improvements in quality of earnings. Audit committee size has been found to vary directly with earnings quality. The larger the size of the audit committee, the more likely that members with financial experience and knowledge are present in sufficient numbers to perform controlling and monitoring functions of financial statements and reporting practices effectively (Baxter \& Cotter, 2009).

\section{METHODOLOGY}

\subsection{Data and measurement of variables}

The study population consists of all listed industrial firms in GCC financial markets outside of the financial sector subject to the condition of availability of all necessary data coupled with, through the period of the study (2014-2018), absence of any incidence of merger or delisting. The data-set totals 23 companies with total of 295 observations as presented in Table 1.

Table 1

Sample selection

\begin{tabular}{|l|c|c|}
\hline Country & Number of banks & No. bank-year obs. \\
\hline Bahrain & 4 & 20 \\
\hline Kuwait & 2 & 10 \\
\hline Oman & 3 & 15 \\
\hline Qatar & 4 & 20 \\
\hline Saudi Arabia & 7 & 35 \\
\hline UAE & 3 & 15 \\
\hline Total GCC & $\mathbf{2 3}$ & $\mathbf{1 1 5}$ \\
\hline
\end{tabular}

Table 2 delimits independent, dependent and control variables cross-referenced by metric. 
Measuring of variables

\begin{tabular}{|c|c|c|}
\hline Variable & Label & Measurement \\
\hline \multicolumn{3}{|l|}{$\begin{array}{l}\text { Independent variables: } \\
\text { Characteristics of Audit Committees: }\end{array}$} \\
\hline Audit Committee Independence & ACIndep & $\begin{array}{l}\text { This committee that totally comprises non-executive } \\
\text { members is given (1), but, in the absence of such } \\
\text { unanimity, then }(0) \text {. }\end{array}$ \\
\hline Audit Committee Size & ACSize & $\begin{array}{l}\text { This was measured through members of that } \\
\text { committee elected by board of directors. }\end{array}$ \\
\hline Number of Audit Committee Meetings & ACMeetings & $\begin{array}{l}\text { This variable was measured through the number of } \\
\text { annual meetings the committee holds. }\end{array}$ \\
\hline Dependent variable: Earnings Quality: & EarQuality & 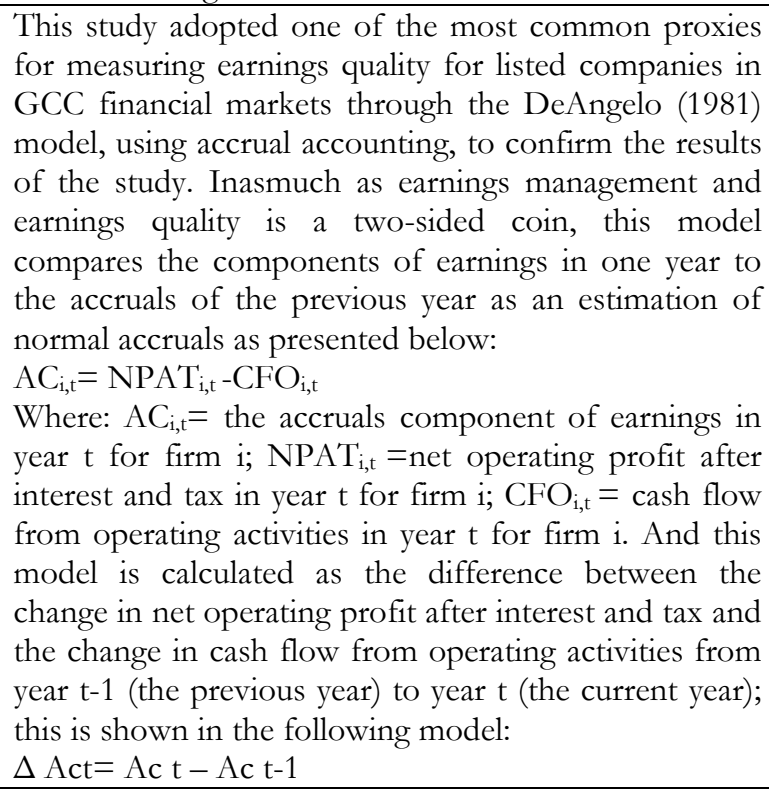 \\
\hline \multicolumn{3}{|l|}{ Control variables: } \\
\hline Firm Size & Size & $\begin{array}{l}\text { The variable of the company size was used as a } \\
\text { controlling one to study the difference between small } \\
\text { and big companies with regard to earnings quality. The } \\
\text { natural log of total assets was used to measure } \\
\text { company size. }\end{array}$ \\
\hline Financial Leverage & FinLev & $\begin{array}{l}\text { Financial leverage uses the overall ratio of debts to } \\
\text { assets. }\end{array}$ \\
\hline Firm Age & Age & The number of years since the firm was established. \\
\hline Industrial control & Sector & $\begin{array}{l}\text { Dummy variable that equals one for particular sector; } \\
\text { otherwise, zero. }\end{array}$ \\
\hline Country dummy & Country & $\begin{array}{l}\text { Dummy variable that equals one for particular country, } \\
\text { otherwise, zero. }\end{array}$ \\
\hline
\end{tabular}

\subsection{Model design}

We employ panel regression analysis to test the impact of audit committee characteristics on earnings conservatism. The basic model is presented as follows:

$$
\text { EarQuality }_{i t g}=\beta_{0}+\beta_{1} \sum_{k=1}^{3} \text { AuditCommittee }_{i t g}+\beta_{2} \sum_{k=1}^{5} \text { Control }_{i t g}+\varepsilon_{i t g}
$$


Where: EarQualityitg is earnings quality, i denotes the firm, $\mathrm{t}$ indexes the year, $\mathrm{g}$ denotes the country, and $\varepsilon_{i t g}$ is the error term. This model is based on panel data collected by observing 23 firms over a five-year period (2014-2018).

\section{EMPIRICAL RESULTS AND DISCUSSION}

\subsection{Descriptive analysis}

From table 3 we notice that the average size of a committee is almost four members, while the largest number of any committee is seven. These results emphasize to the administration that the audit committee should not be very big, as that might lead to a decrease in coordination and problem-solving capacity (Pucheta-Martínez and Fuentes 2007). GCC industrial firms structure audit committees, in terms of size, in compliance with the governance rules. Table 3 shows that the audit committee of the study sample meets four times a year on average. The highest number of meetings was nine a year, and the least was four. This shows that GCC firms abide by the governance regulations regarding the number of meetings of the audit committee.

Table 3

Descriptive of Study Variables

\begin{tabular}{|c|c|c|c|c|}
\hline Panel A: Continuous Variables & Minimum & Maximum & Mean & SD \\
\hline Audit Committee Size & 3 & 7 & 3.850 & 0.645 \\
\hline Audit Committee Meetings & 4 & 9 & 4.250 & 0.457 \\
\hline Total Accruals 000’USD\$ & 1,327 & $25,217,632$ & $2,728,308$ & $5,916,152$ \\
\hline Firm Size 000’USD\$ & 13,245 & $42,947,334$ & $4,358,299$ & $9,142,644$ \\
\hline Financial Leverage & 0.0421 & 0.657 & 0.342 & 0.287 \\
\hline Firm Age & 6 & 67 & 34.500 & 13.250 \\
\hline \multirow{2}{*}{ Panel B: Dichotomous Variables } & \multicolumn{4}{|c|}{ Percentage } \\
\hline & Minimum & Maximum & Mean & SD \\
\hline Audit Committee Independence & 0.250 & 0.950 & 0.790 & 0.245 \\
\hline
\end{tabular}

Table 3 Part B shows that $79 \%$ of the study sample has audit committee members who are distinguished for their independence. The study found that the mean of total accruals was $\$ 2,728,308$ and the maximum was $\$ 25,217,632$. Financial leverage is one of the control variables. The mean of the sample study in this respect was $34.2 \%$. This reflects a big difference because the GCC industrial firms depend on foreign financing when financing their assets. The findings of the study showed that the mean of firm age, another control variable, is 34.5 years. The maximum firm age was 67 years, while the minimum was 6 years.

\subsection{Testing of hypotheses}

When time-series and cross-sectional data are merged, panel data emerges that gives more data information with less disparity, less internal correlation between variables, more degrees of freedom, and more efficiency (Gujarat, 2015). Panel regression models are divided into fixed-effect approach (FE) and random-effect approach (RE). To differentiation between the two approaches we used the Hausman test where a null hypothesis assumes that capabilities of fixed-effect approach (FE) and random-effects approach (EF) are same. In the event that the null hypothesis is rejected, then this is indicative of randomeffect approach is inappropriate; it is, therefore, preferable to use fixed-effect approach. Houseman-chi ${ }^{2}$ 
for the study model shown in table 3 is statistically significant; such a result means that the fixed-effect model (FE) best represents the relationship between audit committee characteristics and earnings quality. Results are depicted in Table 4.

Table 4

Test of Hypotheses

\begin{tabular}{|c|c|c|c|c|}
\hline \multirow{2}{*}{ Hypotheses } & \multirow{2}{*}{$\begin{array}{l}\text { Independent } \\
\text { variables }\end{array}$} & \multicolumn{3}{|c|}{ Fixed-effect results } \\
\hline & & $\beta$ & $t$-Statistic & $p$-value \\
\hline $\begin{array}{l}\mathrm{H}_{1} \text { : Increased independence of audit committees is } \\
\text { associated with earnings quality. }\end{array}$ & $\begin{array}{l}\text { Audit Committee } \\
\text { Independence }\end{array}$ & 0.241 & $2.845^{* *}$ & 0.014 \\
\hline $\begin{array}{l}\mathrm{H}_{2} \text { : Increased audit committees' size is associated } \\
\text { with earnings quality. }\end{array}$ & Audit Committee Size & 0.875 & $3.901 * * *$ & 0.000 \\
\hline $\begin{array}{l}\mathrm{H}_{3}: \text { Increased audit committees' meetings are } \\
\text { associated with earnings quality. }\end{array}$ & $\begin{array}{ll}\text { Audit } & \text { Committee } \\
\text { Meetings } & \\
\end{array}$ & 0.624 & 1.425 & 0.297 \\
\hline \multirow[t]{5}{*}{ Control variables: } & Firm Size & -2.574 & $-3.111 * * *$ & 0.000 \\
\hline & Financial Leverage & 0.136 & 0.755 & 0.932 \\
\hline & Firm Age & 0.946 & $5.505^{* * *}$ & 0.000 \\
\hline & Industrial control & 0.111 & 1.361 & 0.487 \\
\hline & Country dummy & 0.987 & $1.985^{* *}$ & 0.030 \\
\hline \multirow[t]{6}{*}{ Model statistics: } & R Square & \multicolumn{3}{|c|}{0.713} \\
\hline & Adjusted R Square & \multicolumn{3}{|c|}{0.385} \\
\hline & $F$-Statistic & \multicolumn{3}{|c|}{$18.547 * * *$} \\
\hline & $p$-value ( $F$-Statistic) & \multicolumn{3}{|c|}{0.000} \\
\hline & Hausman Test $\left(\mathrm{Chi}^{2}\right)$ & \multicolumn{3}{|c|}{$10.054 * * *$} \\
\hline & $p$-value $\left(\mathrm{Chi}^{2}\right)$ & \multicolumn{3}{|c|}{0.000} \\
\hline
\end{tabular}

Source: Author's results. * indicates significance level at 0.10 level, ** indicates significance level at 0.05 level, *** indicates significance level at 0.01 level.

\section{Testing the first hypothesis:}

$H_{1}$ : Increased independence of audit committees is associated with earnings quality.

This first hypothesis attempts to answer whether or not the independence of members of the committee contributes to the competence which improves earnings quality.

The basic notion is that their independence and control of internal audit and oversight work improves performance and earnings quality (Qaraqish, 2009) and reduces incidence of earnings management (Saleh et al., 2007; Carcello et al., 2006). In the current study, however, the opposite obtains in that dependence of members of the audit committee improves earnings quality. Still, it is emphasizing that Lin and Yang (2006) found no statistically significant influence of member independence on earnings quality. Interestingly, McMullen and Raghunandan (1996) found an inverse relationship between the independence of members of the audit committee, whether executive or non-executive, and the ambit of the committee: the greater the independence, all other things being equal, the less its ambit.

\section{Testing the second hypothesis:}

\section{$H_{2}$ : Increased audit committees' size is associated with earnings quality.}

The second hypothesis aims to test the impact of audit committee size on improvement of earnings quality. According to earlier studies implemented by Hamdan, (2020), Hamdan and Mushtaha (2011) and Felo et al. (2003), there is a positive relationship between audit committee size and earnings quality. Moreover, the size of audit committees, in terms of number of members, impacts incidence of material misstatements published in financial statements: the larger the size, the lesser the incidence (Huang, 2005). Larger audit committee can more effectively participate in the process of preparing the company financial 
statements that ultimately enhances earnings quality (Lin and Yang, 2006). As for the role of the size of the audit committee of listed GCC industrial firms in enhancing earnings quality, consonant with results depicted in Table 3, size of the audit committee varies directly with earnings quality. Accordingly, the second hypothesis, which states that increased audit committee size is associated with earnings quality, is accepted. These results differ from those of Qaraqish (2009) in which audit committee size was found not to be related to earnings quality in Jordanian industrial companies listed on the Amman stock exchange. However, there may be even diminishing marginal return to scale, if not negative returns, from size of audit committee that might decrease the effectiveness of the audit committee where the number of audit committee members becomes unwieldy.

\section{Testing the third hypothesis:}

$H_{3}$ : Increased audit committees' meetings are associated with earnings quality.

The Blue-Ribbon Committee (BRC), in its ten recommendations on audit committee structuring, discounted meeting frequency in the absence of any finding on the impact of the number of meetings on corporate control or on improvement in financial reports quality (Hamdan et al., 2013). Among other studies, Lin and Yang (2006) confirmed an absence of any effect of the number of meetings of the audit committee on the quality of financial reports. Rahman and Ali (2006) and Baxter and Cotter (2009) corroborated this finding. In the current study, likewise, the impact of the number of meetings of the audit committee on earnings quality, as exemplified in the reduction of discretionary accruals in returns exhibited in Table 3 , is nil. “

Among other studies, Change and Walter (1996) indicated that large firms publish higher quality financial reports than the smaller ones. In the current study, an inverse relationship between firm size and the earnings quality is manifest. As for the relationship between financial leverage and earnings quality, no significant relationship, according to the results of the current study, is discernible between them. Many previous studies maintained that older, more established companies exhibit a greater capacity to organize information -- enhancing earnings quality relative to that of young companies. With respect to the current study, Table 4 indicates that the company age varies directly with the earnings quality to a statistically significant extent.

\section{CONCLUSIONS}

In investigating the effect of audit committees on earnings quality, data were collected from 23 listed industrial firms on the GCC financial markets from 2014-2018. Audit committees serve as corporate governance mechanism coordinating internal auditing, external auditing, and monitoring of company performance in support of high-quality financial reporting of corporate performance. Testing the effect of size of the audit committee on earnings quality revealed that the former varies directly with the latter with the caveat that audit committee size should not reach levels in which diminishing marginal returns manifest. Testing the effect of independence of members of the audit committee on earnings quality likewise revealed that the former varies directly with the latter. Testing the effect of the number of meetings of the audit committee on earnings quality revealed no statistically meaningful relationship of the former on the latter such that it is manifest that the number of meetings has no bearing on earnings quality. 


\section{REFERENCES}

Abdelghany, K. (2005) Measuring the quality of earnings. Managerial Auditing Journal, 20(9), 1001-1015.

Abdel-Meguid, A., Fernando, G., Schneible Jr, R., \& Suh, S. (2019). Differential interpretations and earnings quality. Accounting Horizons, 33(2), 59-73.

Ahmed, A.S., \& Duellman, S. (2007). Accounting conservatism and board of director characteristics: an empirical analysis. Journal of Accounting and Economics, 43(2-3), 411-437.

Al-Sharif, I. (2008). Quality of earnings and their relationship to corporate governance: An Empirical Study on the Industrial Sector Firms Listed at Amman Stock Exchange. Arab Academy for Banking and Financial Sciences, unpublished Ph.D dissertation.

Altamuro, J. and Beatty, A. (2009). How Does Internal Control Regulation Affect Financial Reporting? SSRN Electronic Journal, 49(1-2), 58-74.

Ammer, M.A., \& Ahmad-Zaluki, N.A. (2017). The role of the gender diversity of audit committees in modelling the quality of management earnings forecasts of initial public offers in Malaysia. Gender in Management, 32(6), 420440. https://doi.org/10.1108/GM-09-2016-0157

Baioco, V., \& Almeida, J. (2015). Effects of the audit committee and the fiscal council on earnings quality in Brazil. Revista Contabilidade \& Finanças, 28(74), 229-248.

Baxter, P., \& Cotter, J. (2009). Audit committees and earnings quality. Accounting and Finance, 49(1), 267-290.

Beekes, W., Pope, P. \& Young, S. (2004). The link between earnings timeliness, earnings conservatism and board composition: evidence from the UK. Corporate Governance: An International Review, 12(1), 47-59.

Beyer, A., Guttman, I., \& Marinovic, I. (2019). Earnings Management and Earnings Quality: Theory and Evidence. The Accounting Review, 94(4), 77-101.

Carcello, J., \& Neal, T. (2003) Audit Committee Independence and Disclosure: Choice for Financially Distressed Firms. Corporate Governance, 11(4), 289-299.

Carcello, J., Hollingsworth, C., \& Klein, A. (2006). Audit Committee Financial Expertise, Competing Corporate Governance Mechanisms, and Earnings Management, SSRN Electronic Journal. DOI: 10.2139/ssrn.887512

Cho, H., \& Song, B. (2017). Politically Connected Audit Committees, Earnings Quality and External Financing: Evidence from Korea. Asia-Pacific Journal of Financial Studies, 46, 609-634.

DeAngelo, L. (1981). Auditor size and audit quality. Journal of Accounting and Economics, 3(3), 183-199.

Dechow, P., \& Dichev, I. (2002). The Quality of Accruals and Earnings: the Role of Accrual Estimation Errors. Accounting Review, 77, 35-59.

Dechow, P., \& Schrand, C, (2004). Earnings Quality, The Research Foundation of CFA Institute. Charlottesville, Virginia, United States.

Du, K., Huddart, S., Xue, L., \& Zhang, Y. (2019). Using a hidden Markov model to measure earnings quality. Journal of Accounting and Economics. https://doi.org/10.1016/j.jacceco.2019.101281

Farinha, J. and Moreira, A. (2007). Dividends and Earnings Quality: The Missing Link?, Working Paper, University of Porto.

Felo A, Krishnamurthy, F., \& Solieri S. (2003). Audit Committee Characteristics and the Perceived Quality of Financial Reporting an Empirical Analysis, Working Paper, School of Graduate Professional Studies, Malven, www.ssrn.com.

Francis, J. LaFond, R., \& Schipper, K. (2004). The Market Pricing of Earnings Quality, Working Papers, Duke Fuqua School of Business.

Gujarati, D. N. (2015). Basic Econometrics. New York, NY: McGraw-Hill.

Hamdan, A. (2020). Audit committee characteristics and earnings conservatism in banking sector: empirical study from GCC. Afro-Asian Journal of Finance and Accounting, 10(1), 1-23.

Hamdan, A., \& Mushtaha, S. (2011). The Relationship Between Audit Committee Characteristics and Type of Auditor's Report: An Empirical Study on the Public Shareholding Industrial Companies Listed at Amman Bourse. The Arab Journal of Accounting, 14(1), 109-163.

Hamdan, A., Mushtaha, S., \& Al-Sartawi, A. (2013). The Audit Committee Characteristics and Earnings Quality: Evidence from Jordan. Australasian Accounting Business and Finance Journal, 7(4), 51-80. 
Huang, H. (2005). The Effects of Audit Committee Characteristics on Investors Perception of Financial Reporting, Working Paper: Florida International University.

Huynh, Q. L. (2019). Reputation to the vicious circle of earnings quality and financial performance. Economics and Sociology, 12(2), 361-375. doi:10.14254/2071-789X.2019/12-2/22.

Karajeh, A.I.S. (2019). Voluntary disclosure and earnings quality: evidence from ownership concentration environment. Management Research Review, 43(1), 35-55.

Khuong, N. V., Liem, N. T., \& Minh, M. T. H. (2020). Earnings management and cash holdings: Evidence from energy firms in Vietnam. Journal of International Studies, 13(1), 247-261.

Lara, J., Osma, B., \& Penalva, F. (2009). Accounting Conservatism and Corporate Governance. Review of Accounting Studies, 14(1), 161-201.

Larcker, F., \& B. Tayan, B. (2011). Corporate governance matters: A closer look at organizational choices and their consequences (Pearson Education, Inc., FT Press, Upper Saddle River, NJ).

Li, V. (2019). The effect of real earnings management on the persistence and informativeness of earnings. The British Accounting Review, 51, 402-423

Lin, J. and Yang, J. (2006). The Effect of Audit Committee Performance on Earnings Quality. Managerial Auditing Journal, 21(9), 921-933.

Lobanova, O., Barua, A., Mishra, S., \& Prakash, A.J. (2019). Earnings informativeness in dual-class firms: An empirical investigation of the earnings quality and the information environment. Review of Accounting and Finance, 18(3), 399-431.

McMullen, D., \& Raghunandan, K. (1996). Enhancing Audit Committee Effectiveness. Journal of Accounting, 182(2), 79-81.

Ohlson, J., \& Feltham, J. (1995). Valuation and clean surplus accounting for operating and financial activities. Contemporary Accounting Research, 11(2), 689-731.

Pucheta-Martínez, M. C., \& De Fuentes, C. (2007). The Impact of Audit Committee Characteristics on the Enhancement of the Quality of Financial Reporting: an empirical study in the Spanish context. Corporate Governance: An International Review, 15, 1394-1412.

Qaraqish, S. (2009). The Effect of Audit Committee Characteristics on Earnings Quality an Empirical Study on the Industrial Sector Firms Listed at Amman Stock Exchange. Arab Academy for Banking and Financial Sciences. unpublished dissertation.

Rahman, R., \& Ali, F. (2006). Board, Audit Committee, Culture and Earning Management: Malaysian Evidence. Managerial Auditing Journal, 21(7), 783-804.

Rezaee, Z., \& Tuo, L. (2019). Are the Quantity and Quality of Sustainability Disclosures Associated with the Innate and Discretionary Earnings Quality? Journal of Business Ethics, 155, 763-786.

Rezaee, Z., Dou, H., and Zhang, H. (2020). Corporate social responsibility and earnings quality: Evidence from China. Global Finance Journal. https://doi.org/10.1016/j.gfj.2019.05.002

Saleh, N. Iskandar, T., \& Rahmat, M. (2007). Audit Committee Characteristics and Earning Management: Evidence from Malaysia. Asian Review of Accounting, 15(2), 147-163.

Schipper, K. and Vincent, L. (2003). Earnings Quality. Accounting Horizons, 17, 97-110.

Silva, P. (2019). Corporate governance, earnings quality and idiosyncratic crash risk during the 2007-2008 financial crisis. Journal of Multinational Financial Management, 51, 61-79.

Sloan, R. (1996). Do stock prices fully reflect information in accruals and cash flows about future earnings? The Accounting Review, 71(3), 289-315.

Suprianto, E., Rahmawati, R., Setiawan, D., \& Aryani, Y.A. (2019). Controlling generation of family firms and earnings management in Indonesia: The role of accounting experts of audit committees. Journal of International Studies, 12(3), 265-276.

Tee, C., \& Rassiah, P. (2020). Ethnic board diversity, earnings quality and institutional investors: evidence from Malaysian corporate boards. Accounting and Finance. https://doi.org/10.1111/acfi.12485

Teitel, K., \& Machuga, S. (2010). The Interaction of Audit Firm Quality and the Mexican Code of Best Corporate Practices on Earnings Quality. Review of Business Research, 10(1), 32-40. 
Vo, X., \& Chu, T. (2019). Do foreign shareholders improve corporate earnings quality in emerging markets? Evidence from Vietnam. Cogent Economics and Finance, 7(1), 1698940

Wang, M., Lee, M., \& Chuang, J. (2016). Relations among audit committee establishment, information transparency and earnings quality: evidence from simultaneous equation models. Quality and Quantity: International Journal of Methodology, 50(6), 2417-2431.

Yoon, B., Kim, B., \& Lee, J. (2019). Is Earnings Quality Associated with Corporate Social Responsibility? Evidence from the Korean Market. Sustainability, 11(5), 1-20.

Zalata, A., Ntim, C., Aboud, A., \& Gyapong, E. (2019). Female CEOs and Core Earnings Quality: New Evidence on the Ethics Versus Risk-Aversion Puzzle. Journal of Business Ethics, 160, 515-534.

Zhang, M. (2019). Conditional pricing of earnings quality. Finance Research Letters, 30, 306-313. 